\title{
The EU's harmonization requirement for the Turkish insurance industry: From the perspective of Turkey's full membership
}

Cem Berk

Arel University

Niyazi Berk

Bahcesehir University

\section{Recommended Citation}

Berk, C., \& Berk, N. (2017). The EU's harmonization requirement for the Turkish insurance industry: From the perspective of Turkey's full membership. International Interdisciplinary Business-Economics Advancement Journal, 2(1), 42-53.

\section{Revisions}

Submission date: Mar. 17, 2015

1st Revision: Nov. 11, 2015

2nd Revision: May 23, 2016

Acceptance: Jan. 2, 2017 


\title{
The EU's Harmonization Requirement for the Turkish Insurance Industry: From the Perspective of Turkey's Full Membership
}

\author{
Cem Berk ${ }^{1}$ and Niyazi Berk ${ }^{2}$ \\ Arel University, Turkey \\ ${ }^{1}$ cemberk@ arel.edu.tr \\ Bahcesehir University, Turkey \\ 2niyazi.berk@eas.bau.edu.tr
}

\begin{abstract}
This study comparatively analyzes the EU insurance system and the Turkish insurance sector in light of the Solvency II regulation. Topics such as the foundation, certification, restructuring, supervision, and disclosure of insurance companies are also evaluated to determine the Turkish insurance industry's capacity to integrate with that of the EU. Regulations aim to constitute a risk-based capital adequacy model by establishing a relationship between the risks of insurance companies and their financial resources. This requires the adjustment and application of the companies' risk management rules and principles. An example of the standard method is presented to show the capital adequacy ratios of Turkish insurance companies from the perspective of harmonization with the EU single insurance market.
\end{abstract}

Keywords: insurance regulation, EU insurance market integration, solvency requirement, riskbased capital, insurance harmonization

\section{Introduction}

As Turkey continues on its path towards full membership and integration into the European Union (EU), the country has made significant reforms in the regulation and management of its insurance industry to comply with EU standards. For example, there have been significant improvements in the protection of policyholders' rights. The responsibility, accountability, transparency, and reporting standards of the EU insurance system have also largely been adopted by Turkish insurance companies.

The goal of this study is to discuss the key features of Turkish insurance companies in light of recent industry regulations and reforms. The study will also discuss the dynamics of the EU insurance market as well as the potential benefits to various related Turkish parties of integrating the Turkish insurance industry into this market. Finally, common issues in insurance arrangement applications and the integration capacity of Turkey will be evaluated.

\section{Literature Review}

EU financial services regulatory authorities and academicians are keenly focused on the solvency requirement and the harmonization of the insurance industry. Rees, Gravelle and Wambach 
(1999) investigate the arguments for solvency regulation when consumers are fully informed of the insurer's insolvency risk. They find that firms always provide enough capital to ensure solvency unless there are restrictions on the composition of their asset portfolios. This suggests that the role of regulation in insurance markets should be confined to providing consumers with information about the default risk of insurers (Rees et al., 1999).

Beckmann, Eppendorfer \& Neimke (2002) analyze the extent of the integration of the EU market for life and non-life insurance. To calculate this indicator, three different kinds of foreign presence are taken into account: foreign presence through merger and acquisitions, foreign presence through branches and agencies, and direct cross-border sales without a physical presence. The authors' results show that integration is even less advanced for life than for nonlife insurance and that mergers and acquisitions are the dominant strategy by which to access a foreign market.

Schoenmaker (2012) emphasizes that international financial institutions are increasingly run on national lines, as national supervisors force stand-alone subsidiaries to maintain separate liquidity and capital buffers in each jurisdiction. To preserve the internal market in financial institutions, the author's paper proposes a supranational approach to banking and insurance supervision and resolution in Europe. According to the Lester (2014), the large cross-border banks would then be supervised directly by the European Banking Authority, and in case of liquidity and solvency problems, would have access to the Eurepean Central Bank and the newly proposed European Resolution Authority (Schoenmaker, 2012). Steffen (2008) begins with an overview of the current main features of the Solvency II project, including the work of the then Committee of European Insurance and Occupational Pensions Supervisors' (CEIOPS) at the time of writing. After a brief summary of reasons, drivers, and objectives for the proposed new regime, some of the details are described in terms of CEIOPS' published Advice to the European Commission. CEIOPS' Qualitative Impact Studies (QIS) are then examined.

Čihák \& Tieman (2008) analyze the quality of financial sector regulation and supervision in the world. Incorporating supervisory implementation into the study provides an improved means of assessing countries' regulatory systems. The authors find that countries' regulatory frameworks score, on average, below full compliance with the standards. The researchers determine substantial differences in the quality of regulatory and supervisory frameworks across countries, with income level being a major factor (Čihák \& Tieman, 2008). Masciandaro, Nieto, and Quintyn (2009) conducted two studies and underlined that the degree of convergence in supervisory architectures among EU countries is low. Their paper focuses on the network of national agencies. Starting from an analysis of supervisory architectures and governance arrangements, they assess to what extent a lack of convergence could undermine efficient and effective supervision. The main conclusion is that the harmonization of governance arrangements towards best practices would better align supervisors' incentive structures and, hence, would be beneficial for the quality of supervision (Masciandaro et al., 2009).

On the other hand, Davies (2006) describes the ways in which EU law forces member states to reorganize their welfare states, focusing on the effects of free movement and competition principles on health care, education, and social insurance. Davies (2006) then considers the consequences of such reorganizations for national identity and social cohesion, for domestic and 
foreign policy. Since, the reorganizations and integration of insurance industry, in effect create a new welfare for European Union. He considers the consequences of such developments; they probably have far greater implications for national identity and social structure than for welfare itself. It is possible to achieve high quality universal welfare service provision in regulated markets, but the absence of the huge public or quasi-public institutions that are a part of European life will change the texture of society.

Finally, equity analysts of PwC expressed an overwhelming preference to use Solvency II results as their primary metric for December 31, 2015 reporting. At a recent PwC briefing with the insurance equity analyst community to discuss the reporting implications of Solvency II, analysts were optimistic about the level of detail they could expect from the Solvency II disclosures. It was hoped that this would enable the volatility of cash generation and the fungibility of capital within a group to be better understood (Shazia \& Garnsworthy, 2015).

\section{Regulations for EU Single Insurance Market}

Single market insurance, in accordance with the founding treaties, is an area where there are no internal borders. There has been a continuous wave of deregulation since the late 1980s, when the Single Market Program, with minimal harmonization and home country control, was implemented through successive periods for banking, insurance, and the securities markets (Stirbu, 2004). The EU single market in the insurance sector began in 1961, with a general acceptance of the free movement of services with the aim of the approximation of national law (Dreassi \& Miani, 2008). Consumers can freely buy insurance products in a single insurance market in all member states of the European Union, and people can also apply to insurers in any member state other than their own country for insurance for their built-in operations.

A single insurance market in the European Union means to offer new opportunities to increase competition and allow companies to safely access better products (Schoenmaker, 2013), an objective formed through the realization of a competitive insurance sector that will contribute to economic development (Dragos, 2013). Regulations concerning the financial reporting of insurance companies are intended to create strong, consistent, workable, transparent, and comparable financial statements under International Financial Reporting Standards. The integration of the accounts and records of the insurance companies that have been founded in EU countries but are operating outside their countries as well as in the global financial centers have special importance. A harmonization that covers all the insurance and reinsurance companies operating in all branches has been foreseen for the EU (Quaglia, 2012). And as a result of the 2007 financial crisis, regulatory requirements increased significantly over the last few years (Chopra, 2011).

The building blocks of the single financial market can be specified to be the national control and supervision of insurance companies and the mutual recognition of the member states (Linder \& Ronkainen, 2004). The reasons for regulating the EU Single Market can be summarized as follows: increase market liquidity, the efficient allocation of resources, a reduction of the cost of capital and thereby of the price of insurance products, and an increase in the economic growth, employment, and welfare of the European society. 
The EU Solvency regulation aims for a common regulatory framework in the member states to avoid conflicting instructions regarding regulatory requirements. The existing regulations give an insurance company that is established in a member state the authority to provide services by opening branches or agencies in other member states of the Union.

The main risks of insurance companies are credit, market, and operational risks. The amount of regulatory capital that insurance companies must hold against these risks is calculated according to either the standard method or the internal method. The capital adequacy ratio is calculated as the sum of Tier 1 and Tier 2 capital divided by risk-weighted assets. Tier 1 capital refers to capital that is easy to liquidate, such as common stock. The main components of Tier 1 capital are ordinary shareholders' equity, retained earnings, perpetual noncumulative preferred stock, reserves created by appropriations of retained earnings, share premiums, other surpluses, and minority interests. Tier 2 capital refers to capital that is difficult to liquidate or is complicated to calculate. The main components are perpetual deferrable subordinated debt (including debt convertible into equity), revaluation reserves from fixed assets and fixed asset investments, and general provisions. Risk-weighted assets are the outstanding liabilities of the insurance company.

\section{Credit Risk}

This constitutes the main focus of risk managers at financial institutions as well as in regulatory authorities. Regulations with respect to credit risk are mostly intended to eliminate the commercial losses of the financial institutions. Regulatory authorities suggest that the financial institutions develop and apply the models appropriate for their own institutional structure. The capital charges for credit spread risk by some undertakings were seen as too low for AA and AAA corporate bonds but as too high for lower rated and structured bonds and especially for unrated bonds.

\section{Market Risk}

The quantitative results of the above calculation indicate that market risk represents one of the most significant modules for the standard method. The mutual and multiple variables between the covariance and correlations used in the determination of market risk are studied and classified, and the technical assumptions of the Delta Value at Risk (VaR) ${ }^{*}$ are applied to the analytical structure. When a specific risk exists, the portfolio volatility, risk error volatilities, and general risks must be added (Doff, 2008).

\section{Operational Risk}

The regulators of financial markets are demanding a far greater level of insight and awareness from directors about the risks they manage and the effectiveness of the controls they have in place to reduce or mitigate these risks (Firzli, 2012). The suggested method of measuring operational risk is a three-pillar approach adapted to the insurance sector; this approach is also applied in the banking sector and is known as Basel II. It consists of a solvency requirement, supervision, and market discipline. However, as insurance risks are different from banking risks,

\footnotetext{
${ }^{*}$ Delta-VaR is a portfolio metric appropriate to the analytic (variance-covariance) methodology of VaR. The relationship of the Delta-VaR to the $\mathrm{VaR}$ is analogous to the relationship between the option delta and the option price. In this case, however, it measures the sensitivity of VaR to the injection of a unit cash flow in each dimension of the cash flow. The same technique can be applied to existing trades within a portfolio to form a useful and meaningful definition of Component VaR. (For detailed information, see Mark B. Garman, Ending the Search for Component VaR, http://www.fea.com/resources/pdf/a_endsearchvar.pdf.)
} 
the contents of the three pillars should be determined by considering the characteristics of the insurance sector (Berk \& Berk, 2010).

i. Pillar One covers all of the quantitative requirements, such as technical provisions, investments, and the management of the financial assets and financial resources of the insurance companies as well as the conditions of the capital that the companies are required to reserve in order to meet their liabilities. This pillar aims to ensure that firms are adequately capitalized with risk-based capital. Companies may use either the standard formula approach or an internal model approach.

ii. Pillar Two includes the arrangements for developing procedures for risk management as well as the risk controls of supervisory authorities. It includes the Own Risk and Solvency Assessment (ORSA). The European Commission grounds the subjects dealt with in Pillar Two upon the so-called Sharma Report, named after the chairperson of the conference on European Insurance Supervision Agencies (EISA).

iii. Pillar Three deals with auxiliary factors, including the general tendency to harmonize the market reward discipline and financial markets, rating agencies accounting rules for more integrated and transparent insurance market. Yet the harmonization of the European Union disclosure rules is compulsory in terms of looking out for the interests of the other relevant parties, such as financial markets and rating agencies. This ensures that a firm's overall financial position is better represented and includes more up-to-date information.

Contrary to the method used in the EU, in the US, Canada, and Australia, the solvency margins of insurance companies are calculated using the risk-based capital method. These countries also determine the failure or default of insurance companies using the same claim method used by rating agencies. The integration of the legislation and supervision in the financial services sector aims for the convergence of the supervision models in the financial markets. The efficiency of the insurance industry depends on the regulation of the standard applications in the European Union member countries.

The Solvency Capital Requirement (SCR), also defined as target capital, is the capital amount that provides a guarantee to policyholders that an insurance company can meet unexpected losses. The SCR can be calculated using the standard formula discussed in detail by the European Commission (or by an internal model determined by the company itself and approved by the regulatory authority). Reliable risk mitigation techniques are applied in the calculation of the SCR. It must be equal to the VaR, adjusted according to the $99.5 \%$ level of confidence within a one-year period.

The Minimum Capital Requirement (MCR) represents the capital floor that requires the final intervention of the supervisory authorities. The companies have to hold their own eligible basic funds to the extent allowed in order to meet the MCR. It should be calculated in a clear, simple, and auditable way. (When the capital has fallen under the MCR, in cases where the insurance or reinsurance companies continue their activities, it should be equal to the amount that will be faced with an acceptable risk level by the policyholders). The risk-based capital (RBC $=$ adjusted capital/calculated capital) model is used for both life and non-life insurance companies. The risks 
are analyzed in four categories: property risk, insurance risk, interest rate risk, and enterprise risk. In Standard \& Poor's European insurer's capital adequacy model, the base level capital and total adjusted capital provide a company with enough funds to sustain its ongoing activities at a $\mathrm{BBB}$ rating.

A clear, understandable, and comparable financial reporting system allows insurance companies to find further financial resources outside their home member states and cross-border activities. Basically, most member states have already adopted into their national legislation an option that exempts small groups from preparing consolidated financial statements (KPMG, 2011). Insurance enterprises must show the total commissions of all the insurance transactions conducted during the operating period. The enterprises must also disclose all kinds of commissions, especially production, supplementary, collection, and portfolio retention commissions. The issue of publishing Solvency II results will increase in the coming months, but if this demand is not met, it is likely that investors will be seen as a sign of weakness (Shazia \& Garnsworthy, 2015).

The stress test or scenario analyses include significant factors that may cause extraordinary incomes/losses in financial institutions' purchases/sales or that may make risk management difficult. These factors include events that have a low possibility of occurring but that would possibly result in a large-sized loss, influencing all the main risks, including market, credit, and operational risk (Mittnik, 2011). The stress test results should be regularly reported to senior management and to the executive board in certain periods. VaR application is quite successful in explaining these changes except for three or four extreme events that may emerge within a year.

In case of an extreme event, the scenario has a built-in VaR measurement methodology, and modelling is done to better measure the risk. The basic approaches in scenario building include historical scenarios and hypothetical scenarios, and portfolio-specific worst-case scenarios may be used in risk measurement. In order to determine the successes and challenges in the direction of integration, quantitative impact studies (QIS) are applied to insurance companies in parallel with the EU practices, and the capital adequacy ratio is calculated. However, these companies generally apply the standard method.

The economic capital is a buffer against expected shocks in market values. It is a function of market, credit, and operational risk and is often calculated by VaR. Insurance companies and the regulatory authority should then aim to hold the risk capital amount at least equal to the economic capital. The revenues are corrected and the risk-adjusted return on risk-adjusted capital (RARORAC) is calculated by subtracting the expected losses (EL) from the operating profit and by replacing the allocated capital with the marginal economic capital $(\mathrm{ECm})$ of the period (expected return/economic capital). Accordingly, the RARORAC is calculated as; RARORAC = (Revenues-EL)/ECm. The target performance must be greater than the cost of doing business and, in particular, larger than the return that the shareholders of the financial institutions are anticipating. For each transaction, the RARORAC ratio should be at least more than the cost of the capital.

The international reporting standards approved by the Accounting Standards Board are widely used by most multinational insurance companies. The rating of the insurance company provides 
an indication for policyholders, agencies, brokers, investors, and the insurance company itself on the subject of the soundness and the credibility of the financial structure (Deloitte, 2008). The early warning indicators can be quantitative and qualitative, and periodical reports or extraordinary reports give some signals. It is especially easy to observe the changes in customer account structure related to property and liability insurance through financial reports (CEIOPS, 2010a). An insurance company should develop the right strategies and should protect the financial structure of the company to determine the marketing policies when entering into a new branch. Establishing cost-benefit requires a determination of the market segments. Protective measures should be taken to protect both consumers and shareholders against insurance failure (disclosure requirements).

The reassurance contracts may be carried out as voluntary or treaty agreements. The regulatory authorities rely on the reassurance programs of the insurance companies when it comes to risk surveillance. The International Association of Insurance Supervisors also assigns special importance to the role of the reassurance and the reduction of hazards through alternative methods of risk transfer. The triangulation method (a method involving the use of multiple data sources in an investigation to produce understanding) is most widely applied in the EU. The triangulation method is applied on a paid indemnities basis.

Difference methods are applied to calculate risk in EU countries. However, the majority of insurance companies apply the loss rate method suggested by the insurance supervisory authority in Germany. In Denmark, actuarial methods are widely used to determine the incurred but not yet reported outstanding indemnities. The Barnhuetler \& Ferguson method (where the amount for expected unreported losses is added to actual reported losses to obtain the estimated ultimate loss for a given year) is used widely in France along with the triangulation method. On the other hand, triangulation method-based indemnity is the method in widespread use in the UK, Italy, Portugal, Spain, and Sweden. Small insurance companies with variable business volume primarily apply the loss rate and average indemnity method. The required capital is calculated for all risks at the appropriate confidence interval.

Liability insurance coverage for all branches of insurance is required in all member states. The insurance companies belonging to an insurance group are not audited according to complementary supervision (the solo-plus approach). The adjusted solvency of the audit should be calculated, and the transactions between groups must be reported. Supervision of cross-border groups remains the primarily liability of the home country supervisors. In order to prevent double or multiple gearing derivation of the capital among group companies, consolidation is applied.

\section{The EU Integration Process for Turkish Insurance Companies}

The solvency study that has been ongoing for over 10 years in the EU has been followed closely. In 2009, when the EU regulation on this subject was publicized, studies in Turkey accelerated as well. The expertise commission constituted within this framework finished the QIS4 study in 2010. With these studies, preparation for Solvency II and the insurance companies' awareness increased in Turkey. According to a declaration publicized by CEIOPS on December 16, 2010, the participation rate in QIS5 increased compared to QIS4 and rose to 70\% from 33\%. So an important step has been taken in the Turkish insurance industry on the way to Solvency II 
integration (CEIOPS, 2010b). The support of a company's executive board appears to be the most critical success factor for companies from Turkey participating in the survey. To obtain membership, screening, negotiation, and a ratification process are required.

Screening is the examination of the candidate country's legislation from the perspective of the EU Acquis communitarian by the authorities of the European Commission. This process is carried out separately for each chapter of the Acquis. Within this framework, the legal norms that do not comply with the Acquis are required to be amended. During the negotiation period, the candidate country presents to the EU its negotiation position for each chapter, and the EU member states ask questions of or request clarifications from the candidate country. Subsequently, the candidate country is invited to a negotiation for a specific chapter. Insurance services are in the chapter on the free movement of financial services.

A newly introduced arbitration system in Turkey aims to resolve potential disputes arising from the insurance contract between the policyholder or the beneficiary of the insurance contract and the party undertaking the risk. An ombudsman system based on international practices has been constituted according to the structure and basic principles of the arbitration system found in the Code of Civil Procedure in the EU regulation. A survey carried out in 2010, in which 115 insurance and reinsurance companies in life and non-life branches participated, draws attention to the important points, critical success factors, and difficulties on the way to Solvency II integration. There were seven participants from Turkey. The 2011 survey of the perceived risks in insurance is also important, as Turkey participated for the first time, with the second-highest number of participants. Turkey performed better than average in recent years.

In the EU integration process, during the negotiations, the difference between Turkish and EU insurance is important in terms of the consumer information system. Once all the negotiations are completed and it is determined that the candidate country has fulfilled all of the official responsibilities arising from EU membership, a Draft Accession Agreement is issued. The agreement must be undersigned both by the Council of Ministers of the EU and by the European Parliament. After the agreement is signed, in order to come into force, it must be accepted by all the member states (in accordance with decisions to be taken by the national parliaments) and by Turkey (with the decision of the Grand National Assembly of Turkey).

\section{Methodology}

Confidential data, including financial statements and other information, was obtained from a medium-sized company representative of the insurance industry in Turkey. Detailed information and data from the observed company were analyzed to compare with that of EU insurance companies. Another reason for selecting this specific company was its size and the availability of data. The procedure used in this study involved the following steps: Identification of companies that made up the sample, examination of company financial statements, determination of the of premiums to reserve ratio, application of the standard method determined by the regulatory authority, uploading of the company's data to the system, calculation of the capital adequacy, and interpretation of the results.

Experts of the insurance company and the supervisory authority analyze the relationship of insolvency risk and risk-based capital of the company. It should be noted that the company's 
relationship with affiliated institutions posed an important condition in evaluating the solvency of the insurance company; all stock, mutual, reciprocal property, and liabilities with admitted assets and net premium incomes for the analyzed period for the insurance company are considered. It was ascertained that the insurance company did not have any capital structure problems during the operation period.

The most important outcome of the investigation and analysis was related to the standard method, which applied to all Turkish insurance companies and which was determined by the regulatory authority. The sample is accepted as representative, since all insurance companies are evaluated based the same method. A significant limitation of our investigation, study, and analysis is that the predictive accuracy of the capital structure risk in view of the premium collection from insureds covered by an insurance policy should base on the prudential regulation.

\section{Findings}

The solvency regulation requires insurance companies to establish internal control and risk management units under the supervision of a general manager or CEO. Turkish insurance companies carry out activities based on legal policies and principles. The most important point introduced with the new insurance directive is that insurance companies with good corporate governance practices are allowed to hold relatively less capital. The required equity capital according to the regulations is calculated separately for non-life, life, and pension insurance branches. The solvency capital requirement is reported on the premium basis as well as on a claim basis.

\section{The Required Equity Capital on the Premium Basis}

This is the amount computed if the rate of the total amount obtained after terminations and cancellations is deducted (except tax and charges) from premiums underwritten within the previous year, up to $\$ 25$ million. This amount is multiplied by $18 \%$, and the remaining amount is multiplied by $16 \%$. According to the rate of net claim, if the gross damages of the company in the last year are less than $50 \%$, it is multiplied by $50 \%$, and if the damages are more than $50 \%$, it is multiplied by the rate computed.

\section{The Required Equity Capital on the Claim Basis}

This is the capital computed if the rate of total amounts obtained after the deduction of $1 / 3$ and 1/7 from the outstanding indemnity. It include also incurred but not reported reserved three years ago, except the current year and the claim compensations collected through recourse after the outstanding indemnity reserves of the last one year. This amount is added to the gross paid indemnity settlement from the last three years, which is reserved according to the risk determination. This amount is multiplied by $25 \%$ up to the first $\$ 70$ million, and the remaining amount is multiplied by $23 \%$, to obtain the company's previous year's rate of net indemnity. If the total indemnity is less than $50 \%$, it is multiplied by $50 \%$. If it is more than $50 \%$, it is multiplied by the rate computed.

The risk-based capital includes the asset risk, reinsurance risk, off-balance sheet risk, the risk of excessive premium increase, and the underwriting risk. In the required capital calculation using the second method, the asset risk, reinsurance risk, excessive premium increase risk, outstanding claim provision risk, and underwriting risk as well as the interest rate and currency risk are 
considered. To calculate the asset risk, asset items are multiplied by their risk weights. For example, cash and T-bills (including Eurobonds) are multiplied by 0.000, bank accounts are multiplied by 0.010 , and shares pertaining to own capital are multiplied by 0.250 . The results of premiums and claims are compared, and the higher result is determined as the required capital for the insurance company.

Table 1: The Statement of Capital Adequacy

\begin{tabular}{lc}
\hline Calculation of the capital adequacy of an insurance company (\$000) & Year \\
\hline Date the table uploaded into the system (portal by the Supervisory Authority) & \\
Deadline for the companies to load the table into the system (portal) & yearly \\
Frequency & 145,544 \\
1- According to premium basis & 41,159 \\
2- According to claim basis & 145,544 \\
I. Equity required for non-life branch & 0 \\
1- Result concerning liability & 0 \\
2- Result concerning risk & 0 \\
II. Equity required for life branch & 0 \\
III. Equity required for pension branch & 145,544 \\
Required equity according to the claim method & 121,570 \\
1- Asset risk & 6,750 \\
2- Reinsurance risk & 29,775 \\
3- Excessive premium increase risk & 2,738 \\
4- Outstanding indemnity risk & 98,004 \\
5- Underwriting risk & 155 \\
6- Exchange risk & 258,992 \\
Required equity for the company & \\
Equity & 400,000 \\
Paid in capital (common stock) of the company & 5,200 \\
Positive distinction from share capital integration & 0 \\
Negative distinction from share capital integration & 220,186 \\
Profit reserves & 14,868 \\
Capital reserves & \\
Net income of the period incl. reserves and retained earnings of previous year's profits & \\
equalization provision (259,011 + 459,011) & \\
30\% of subordinated debts & $-2,288$ \\
Total loss of period and losses of the previous year & 637,966 \\
Total equity & \\
Total amount paid in capital of companies that are among the subsidiaries, affiliated companies, long- & \\
term securities, group companies (insurance, pension, reinsurance) by the participation of undertaking & \\
companies & \\
Result of capital adequacy & $\mathbf{3 7 8 7 4}$ \\
\hline
\end{tabular}

If the calculated value of the premiums is lower than the value of the claims $(145,544>41,159)$, the solvency capital required for the company is the premium-based amount $(145,544)$. The risk capital is calculated according to the second method for the risk of assets, so this total is $258,992$. This amount is subtracted from the equity of the company (losses of the prior period are deducted from the equity); accordingly, the solvency capital is $637,966-258,992=378,974$. Since the capital is positive and is a considerable amount, the company is unlikely to have a capital problem in terms of insolvency under normal market conditions.

If the calculated value is negative, the supervisory authority instructs the insurance company to increase the equity capital above the minimum regulatory threshold within a given time frame. If 
the capital requirement is not satisfied, the supervisory authority may take control of the firm's management, impose restrictions on the firm's operating activities, and, as a last resort, terminate the firm's license as it is in the EU.

\section{Conclusions}

Integration with the European insurance market benefits both insurance companies and consumers. Insurance companies benefit from the improved regional diversification of insured risks, the realization of economies of scale, and a wider area for capital investment. Consumers benefit from higher competition among insurance companies and better pricing for insurance products. By promoting cost-awareness, the Single Market regulation provides insurance managers an opportunity not only to apply a more rational pricing policy but also to innovate new products and methods.

Solvency rules stipulate the minimum amounts of financial resources that insurers and reinsurers must have in order to cover the risks they are exposed to. As a result of effective supervision in the solvency system, insurance companies improve disclosure and transparency and focus on protecting the interests of their stakeholders. Also, through early warning signals, the companies may be protected from default or insolvency. Thus, a harmonization between prudential regulatory supervisory authorities and companies can also be established with respect to the protection of insurance stakeholders' benefits.

Full harmonization with the EU regulation in some troubled fields may be the result of an openended transition period or some temporary exemptions. The Turkish insurance legislation is largely already harmonized with the EU Insurance Acquis. Turkish insurance companies have also long been working in harmony with European insurance and reinsurance companies. Nevertheless, more effective regulation and supervision of insurance companies and requirements for them to prepare financial statements in accordance with the EU legislation will certainly facilitate the harmonization process.

Managers of Turkish insurance companies generally believe that Turkey's membership in the EU would be beneficial for the Turkish insurance market. However, applying internal risk models during the transition period will be costly for Turkish insurance companies, since the profitability of the insurance sector is likely to fall. However, in the medium and long term, these new models will pay off, and the efficiency of the industry is expected to improve. In summary, insurance in Turkey is one of the industries that may integrate into the EU relatively more easily than other sectors.

\section{References}

Beckmann, R., Eppendorfer, C., \& Neimke, M. (2002). Financial integration within the European Union: Towards a single market for insurance. Retrieved from https://mpra.ub.unimuenchen.de/5280/1/MPRA_paper_5280.pdf

Berk, C., \& Berk, N. (2010). Estimating loss given default in insurance companies: Operational research society. Journal of Economics and Administrative Sciences, 29(2), 251-273.

Chopra, A. (2011, October). Strengthening the financial stability framework of the EU. Paper presented at the 2011 Dublin Economic Workshop of the Kenmare Conference, Dublin, Island.

Čihák, M., \& Tieman, A. (2008). Quality of financial sector regulation and supervision around the world. (Research Working Paper No. 08/190). Retrieved from Social Science Research Network (SSRN) website: https://ssrn.com/abstract=1266523 
Committee of European Insurance and Occupational Pensions Supervisors. (2010a). CEIOPS' advice for level 2 implementing measures on solvency II: SCR standard formula article 111(I) simplified calculations in the standard formula. Retrieved from https://eiopa.europa.eu/CEIOPS-Archive/Documents/Advices/CEIOPSL2-Advice-Simplifications-for-SCR.pdf

Committee of European Insurance and Occupational Pensions Supervisors (2010b). Fifth quantitative impact study: Call for advice and technical specification. Retrieved from https://eiopa.europa.eu/

Davies, G. T. (2006). The process and side-effects of the harmonization of European welfare states (Research Working Paper No. 02/06). Retrieved from Social Science Research Network (SSRN) website: https://ssrn.com/abstract=900934

Deloitte, L. L. P. (2008). The IFRS journey in insurance: A look beyond the accounting changes. Retrieved from https://www.iasplus.com/en/binary/dttpubs/0808ifrsinsurance.pdf

Doff, R. (2008). A critical analysis of the solvency II proposals. The Geneva Papers on Risk and Insurance - Issues and Practice, 33(2), 193-206.

Dragos, S. L. (2013). Regulatory framework in the insurance industry: The solvency II project. International Journal of Academic Research in Business and Social Sciences, 3(5), 336-347.

Dreassi, A., \& Miani, S. (2008). The European solvency margin: An update for Italian non-life insurers. International Review of Business Research Papers, 4(5), 44-54.

Firzli, M. N. J. (2012). A critique of the Basel committee on banking supervision. Revue Analyse Financière, 1, 220.

KPMG. (2011). Solvency II: A closer look at the evolving process transforming the global insurance industry. Retrieved from https://www.kpmg.com/US/.../solvency-II.pdf

Lester, R., (2014). Insurance and inclusive growth: The world bank finance and markets global practice (Working Paper No. 6943). Retrieved from World Bank website: https://openknowledge.worldbank.org/handle/10986/18830

Linder, U., \& Ronkainen, V. (2004). Solvency II: Towards a new insurance supervisory system in the EU. Scandinavian Actuarial Journal, 6, 462-474.

Masciandaro, D., Nieto, M. J., \& Quintyn, M. (2009). Will they sing the same tune? Measuring convergence in the new European System of financial supervisors (Working Paper No. 09/142). Retrieved from International Monetary Fund website: https://www.imf.org/en/Publications/WP/Issues/2016/12/31/Will-they-Sing-theSame-Tune-Measuring-Convergence-in-the-new-European-System-of-Financial-23072

Mittnik, S. (2011). Solvency II calibrations: Where curiosity meets spuriosity (Working Paper No. 04). Retrieved from Center for Quantitative Risk Analysis (CEQURA) website: https://www.cequra.unimuenchen.de/download/solvency.pdf

Quaglia, L. (2012). The European Union and global financial harmonization (Working Paper No. 2012/04). Retrieved from European University Institute website: http://cadmus.eui.eu/handle/1814/22234

Rees, R., Gravelle, H., \& Wambach, A. (1999). Top of form regulation of insurance markets, The Geneva Papers on Risk and Insurance Theory, 24, 55-68.Schoenmaker, D. (2012). Banking supervision and resolution: The European dimension. Law and Financial Markets Review, 6(1), 52-60.

Schoenmaker, D. (2013). Post-crisis reversal in banking and insurance integration: An empirical survey. Retrieved from http://ec.europa.eu/economy_finance/publications/economic_paper/2013/pdf/ecp496_en.pdf

Shazia, A., \& Garnsworthy, C. (2015). Solvency II poised to take top spot for insurance reporting metrics (Web log comment). Retrieved from http://pwc.blogs.com/press_room/2015/10/pwc-solvency-ii-poised-to-take-topspot-for-insurance-reporting-metrics.html

Steffen, T. (2008). Solvency II and the work of CEIOPS. The Geneva Papers on Risk and Insurance-Issues and Practice, 33(1), 60-65.

Stirbu, C. (2004). Financial market integration in a wider European Union. Retrieved from http://ageconsearch.umn.edu/bitstream/26331/1/dp040297.pdf 